\title{
Project for the development of Oriental studies in Kazan in the early 19th century: On opening vocational schools for Oriental languages in the Kazan school district
}

Ramil Valeev ${ }^{1}$

Roza Valeeva ${ }^{2}$

Dinar Khayrutdinov ${ }^{3}$

\author{
Journal for Educators, Teachers and Trainers, Vol. 12 (1)
}

\section{https://jett.labosfor.com/}

Date of reception: 05 October 2020

Date of revision: 03 January 2021

Date of acceptance: 02 April 2021

Ramil Valeev, Roza Valeeva, Dinar Khayrutdinov(2021). Project for the development of Oriental studies in Kazan in the early 19th century: On opening vocational schools for Oriental languages in the Kazan school district. Journal for Educators, Teachers and Trainers, Vol. 12(1). 117 - 122.

${ }^{1}$ Department of Altaic and Chinese Studies, Institute of International Relations, Kazan (Volga Region) Federal University - Kazan, Russia

${ }^{2,3}$ Department of International Languages and Translation Studies, V. G. Timiryasov Kazan Innovative University - Kazan, Russia 


\title{
Project for the development of Oriental studies in Kazan in the early 19th century: On opening vocational schools for Oriental languages in the Kazan school district
}

\section{Ramil Valeev $^{1}$, Roza Valeeva ${ }^{2}$, Dinar Khayrutdinov ${ }^{3}$}

${ }^{1}$ Department of Altaic and Chinese Studies, Institute of International Relations, Kazan (Volga Region) Federal University - Kazan, Russia

${ }^{2,3}$ Department of International Languages and Translation Studies, V. G. Timiryasov Kazan Innovative University - Kazan, Russia

Email ID: valeev200655@mail.ru,valroz@inbox.ru,dynx27@gmail.com

\begin{abstract}
Today Russian academic centers, including Kazan Federal University, are unique comprehensive research and education institutions that conduct research on both classical and modern subjects and implement original professional educational programs. In the history and culture of the peoples of Russia and the historical and cultural area of Volga-Urals in particular, Kazan University and its schools of sciences have played an exceptional role. The period from the late 18th to the early 20th centuries was marked by successful development of Asian and African research in Russia and Europe. A cohort of outstanding Russian orientalists, who represented many various ethnic groups of Russia, have provided globally relevant complex philological, historical, archaeological and ethnographic studies in academic and university centers of our country. Oriental studies became an important educational and scientific discipline and area of focus starting from the earliest days of the university community of Kazan. Lecturers and professors of Kazan Imperial University introduced the society to the history and culture of the peoples of both overseas East and the Eastern part of the Russian Empire, as well as expanded the understanding of the cultural legacy of both ancient and modern Asia. The article presents an analysis of the official project developed by the Board of Foreign Affairs of the Russian Empire and devoted to the formation of Oriental studies (including the research of Asian and African languages) in Kazan in the early 19th century.
\end{abstract}

Keywords: Russia, the East, Kazan University, Oriental studies, Asian and African languages, Russian MFA project.

\section{INTRODUCTION}

In the 19th - early 20th centuries, Russian universities, including Kazan University, played an important role in the implementation of the classical model of the "ideal university" and the "university idea" in their social, political, academic and cultural missions (Andreev; Artemyeva, Mikeshin). Oriental studies and orientalism as new branches of the Russian university structure of the modern age were becoming organic in the implementation of the European ideals of a classical university, in the "rise and expansion of science", "increment in scholarly knowledge", in the development of the intellectual capabilities and the personality of the students, etc. In particular, Russian university charters of 1804, 1835, 1863, 1884 developed the institutional bases for models of classical and applied Oriental studies in the higher educational institutions of Russia. The trend of the academic Oriental science narrowing its focus and creating numerous niche specialties that continued throughout the 19th century was associated with the requirements of the "pure science", as well as training personnel for state service in the Empire. Russian universities became the most important institutional structure of the classical Oriental studies. In general, the development of academic knowledge about Asia and Africa in Russian universities was predetermined by various geopolitical, political and cultural factors.

\section{MATERIAL AND METHOD}

The primary methodology of this study is based on the system of various modern principles and ideas philosophical, epistemological and logical ones - that play a defining role in studying trends and objective contents of the history of Oriental studies in Russia and Europe, the centers of academic Asian and African studies of Russia and Europe and the academic heritage of the founders of Oriental education and research. The authors of the paper use a system of methods - both general ones characteristic of Asian and African studies and 
specific ones borrowed from other social sciences and humanities. The leading methodological principle is the historical or historical-scientific principle based on the involvement of original archival materials.

\section{RESULTS}

Official events of the Peter I era - activation of the Eastern policy, government decrees on teaching Oriental languages and inviting European professionals and academics, foundation of the Kunstkamera (1714) and the Academy of Sciences (1725), unique academic travels of scientists to the Volga region, Siberia and the Caucasus (1730-70s) and generally the Eurasian Russia epoch (the bridging of borders with the countries of the "Russian East" and the foreign East, Russian-Asian military-political, diplomatic and cultural relations, etc.) became the factors in the formation of a special branch of researching Oriental languages and scientific knowledge about the East in Russia. The turn of the 19th century was a turning point in the history of Orientalism in the Russian Empire.

Various papers and books on the history of Russian Oriental studies mention several projects aimed at establishing schools of Oriental languages in the "Russian East" (including Kazan) at the initiative of the Board of Foreign Affairs (1806). In particular, this includes a project of the Trustee of the Kazan School District S. Y. Rumovsky, who in November of 1806 proposed "to establish 'the main school for Oriental languages' at Kazan Grammar School" (Baziyants, Grinkurg, 42; Kulikova, 135; Kiselev, 66-74). A. M. Kulikova, a historian of Russian Oriental studies, mentions a project of creating an Asian Institute in Kazan in the 1840s. Historians of Kazan Oriental studies G. F. Shamov, A. S. Shofman, N. A. Mazitova, S. M. Mikhailova, and R. M. Valeev note various Kazan-related projects of Oriental education and research dating back to the first half to the middle of the 19th century (Shamov, 83-86; Mikhailova, 66). Nevertheless, there are still very few comprehensive studies covering projects on the formation and development of Oriental studies in Kazan in the 19th - early 20th centuries as well as on the history of Russian Oriental studies in general.

In 1806, at the initiative of the Ministry of Foreign Affairs, a project titled "On opening vocational schools for Oriental languages in the Kazan School District" appears (Russian State Historical Archive). The main correspondence concerning this project took place in the August - November of 1806 between the Minister of Foreign Affairs A. J. Budberg (1806-1807) and the Minister of National Education P. V. Zavadovsky (18021810). The draft report "concerning the establishment of schools for Oriental languages" at Kazan University and in the Kazan School District was actively discussed in the Main Department for Vocational Schools of the Ministry of National Education on October 11, 1806. The key place in the project was assigned to the creation of the "main school for Oriental languages" in Kazan. The idea of having "institutions for Oriental languages in vocational schools" in the Kazan School District, particularly in Kazan, Irkutsk and Tiflis, was associated with an acute shortage of translators "for Oriental languages in the State Board of Foreign Affairs, especially ones that are natural Russians", and "for lack of necessary institutions for training" (Russian State Historical Archive, 1.1 .

Of particular interest is the "Draft report on the Asian part" by Minister of Foreign Affairs Alexander Budberg. Besides the Tatar class, it was supposed to "create similar classes for Arabic and Turkish" at Kazan Grammar School, while in Irkutsk Grammar School, "in addition to the Japanese class established there, to establish similar classes for Chinese and Manchu" and "to teach Georgian and Armenian in Tiflis at the Persian school there" (Russian State Historical Archive, 1. 2-4). This particular plan is one of the first government reforms of the state system of Russia at the beginning of the 19th century, which expanded the structure and focus areas of Oriental science in new educational districts. According to these plans, the Kazan School District was given a primary place in the development of Oriental studies in the first half of the 19th century.

Paragraph 17 of the official "draft report on the Asian part" read: "Assuming two students for each language, it will be necessary for all languages to have fifteen pupils, who are to be recruited mainly from among the children of company officers or clerks, and in the case of a lack of any such children they are to be recruited from military orphanage schools, but we need to ensure that they are from among natural Russians, or at least from among baptized Tatars, and that before entering these schools they have already mastered certain basics of learning, that is, that they know calligraphy, spelling, arithmetic and Russian grammar so that later, while they learn languages, they can be also taught geography, history and other sciences." (Russian State Historical Archive, 1.2-4) These principles confirm the new political, social and educational orientation of the Imperial government policy in the field of Oriental education and science, which expanded in Russia during the 19th early 20 th centuries.

Teaching Oriental languages was mainly aimed at training qualified government officials who were to serve the expanding domestic and foreign policy interests of the Russian state in the "Russian East" and the foreign East. After completing their studies in schools, students had to spend "at least a year at Kazan University to improve" their level of Oriental languages. Subsequently, the graduates would receive state positions of translators "at the Tsargrad mission, at Consulates in the Levant", "at Astrakhan, Caucasian, Georgian, Ekaterinoslav, Orenburg and Siberian military governorates, at the upper border court in Mozdok, at the border commissions in Orenburg and Kyakhta", etc. These government measures show the goals and focus areas of the formation of Russian 
Imperial Oriental studies. Being a part of this process, Kazan and Imperial Kazan University became a symbolic "window to the East" (Gerasi).

Special attention was paid to experts in Chinese and Manchu, who were to be assigned "to the Spiritual mission in Beijing, for improving their skills, in student positions there." According to Paragraph 20 of the "Draft report on the Asian part", two best students of the Kalmyk language were to be placed "in Kazan University's Grammar School, so that they are also trained in different sciences", and subsequently they were supposed to be sent "to different positions" in Kalmyk uluses. This project was transferred to Trustee of the Kazan School District S. Y. Rumovsky "for consideration, taking into account the local circumstances and messages about his opinion, as well as about the existing schools of Oriental languages in the Kazan District, and for detailed information" (Russian State Historical Archive, 1. 5).

Interesting materials about the level and state of research of Oriental languages in Kazan, Orenburg, Tobolsk and Irkutsk contain a letter from the trustee of the Kazan School District dated November 12, 1806. It proposed to establish classes of Arabic and Turkish, Japanese, Chinese and Manchurian, Persian, Georgian and Armenian languages at Kazan Grammar School "in addition to the Tatar class" (Russian State Historical Archive, 1. L. 11 $11 \mathrm{ob}$.). The poor level of teaching Oriental languages in public vocational schools was often due to the low level of qualification of teachers and them focusing solely on reading and writing. In this message of the Trustee, the preference was given to the Kazan Grammar School and due to the fact that "Mr. Frähn ${ }^{1}$ (Frähn, Khristian Danilovich (Germ. Christian Martin Joachim Frähn (1782-1851) was an outstanding German and Russian orientalist - arabist and numismatist. Professor of Kazan University (1807-1815), Academician of the St. Petersburg Academy of Sciences (from 1817), Full State Councilor. In 1818-1842, he headed the Asiatic Museum of the Academy of Sciences. He was an honorary member of more than 20 academies and scientific societies of the world, as well as the author of more than 150 studies published in Russian, German, Latin, and Arabic (Frähn, 248 - 251).) accepted the title of Professor, he will be the judge of the teachers' knowledge, and classes of Oriental languages can be entrusted to his supervision." (Russian State Historical Archive, 1. 11 ob.) The main point made by the Trustee of the Kazan School District, S. Y. Rumovsky, was the importance of opening the "main school for Oriental languages" in Kazan and, subsequently, establishing classes at vocational schools in Irkutsk, Tobolsk, Orenburg and Tiflis and thus meeting the requirements of the Board of Foreign Affairs (Russian State Historical Archive, 1. 2).

This project, of course, tried to develop and implement the ideas and principles for teaching Oriental languages that were laid down back in the 1880s, when a system of vocational schools was created by famous educational reformer F.I. (Teodor) Janković Mirijevski (Voronov; Kulikova, 33-38; Istoriya otechestvennogo..., 63-64). The basis for the development of teaching Oriental languages in Russia in the last quarter of the 18th century in his project was the formation of a special school of Oriental studies. Unfortunately, this long-term plan was not implemented. We should also pay attention to the fact that there is no direct connection between the projects of the late 18th century and the ones from the early 19th century. The new interest of the Board of Foreign Affairs in teaching Oriental languages in the early 19th century was due to the government needs and interests in pursuing an active foreign policy of the Russian state in the East.

\section{DISCUSSION}

The Volga and Urals regions, and above all their major economic, political and cultural center - Kazan and Kazan University - have for many centuries played the leading role in the military-political, historical and cultural interaction of Russia with the countries and peoples of the East. This geopolitical and cultural factor became fundamental in the formation and development of Oriental studies at Kazan University. In the 16th 19th centuries, the regions and peoples of the East gradually became a part of the emerging Russian Empire (the Volga-Urals region, Siberia, Crimea, the far East, the Caucasus, and Central Asia), and these complex processes of integration of peoples and ethnic groups with a variety of religions and cultures set the task of studying each other and learning each other's cultures. Kazan University, as the only Eastern university in the 19th century, played the leading role in the formation of objective ideas and knowledge about the history and culture of the peoples of the East. Various research projects on the development of Oriental studies at Kazan University and in Kazan in general also played an important role.

\section{CONCLUSION}

In the 19th - early 20th centuries the Academy of Sciences and the university centers played a key role in the changing of the status, structure and nature of Oriental studies, and a large contribution to this institutional and research process was made by representatives of the peoples of Russia and Europe - Tatars, Azerbaijani people, Jews, Georgians, Armenians, Polish people, French people, Germans, etc. The multi-ethnic nature of the Oriental studies in Russia is an important humanitarian, social and cultural tradition in this country's scholarly research of the historical and cultural legacy of the East.

Important social and political milestones and external criteria in the genesis of academic research of the East were the development of the Russian Imperial and Soviet state and society, primarily the directions and 
outcomes of the Eastern policy during the periods in question. In the intra-scientific institutional evolution and typology of the academic discipline, the most important stages are ones associated with the activities of Oriental departments and divisions in Russian universities and institutes (Kazan and St. Petersburg Universities, Lazarev Institute of Oriental Languages, etc.), the creation of the Oriental faculty of St. Petersburg University (1854/1855) and the Oriental Institute in Vladivostok (1898), as well as various projects aimed at developing the teaching of Oriental languages in the Empire and the creation of new Oriental studies institutes in the 19th and the early 20th centuries, and later during the first decades after the Socialist Revolution various reorganization periods of Oriental institutions during the formation stages of the Soviet state in the years 1917 to 1930 s.

\section{ACKNOWLEDGEMENTS}

The work has been performed under the Russian Government Program of Competitive Growth of Kazan Federal University, RFBR project № 20-09-00385 A.

\section{REFERENCES}

1. Andreev, A. Y. (2009). "Ideya universiteta" v Rossii (XVIII - nachalo XX v.) ["The university idea" in Russia (18th - early 20th centuries)] in "Byt' russkim po duhu i evropejcem po obrazovaniyu": Universitety Rossijskoj imperii v obrazovatel'nom prostranstve Central'noj i Vostochnoj Evropy XVIII - nachalo XX v. ["Being a Russian in spirit and a European in education": Universities of the Russian Empire and the educational space of the Central and Eastern Europe of the 18th - early 20th centuries]. Moscow.

2. Artemyeva, T. V.; Mikeshin, M. I. (ed. by) (2005). Istoriya universitetskogo obrazovaniya v Rossii i mezhdunarodnye tradicii prosveshcheniya [The History of university education in Russia and the international traditions of education]. Vol. 2. Saint Petersburg.

3. Baziyants, A. P.; Grinkurg, I. M. (1984). Tri proekta organizacii izucheniya vostochnyh yazykov i Vostoka v Rossii v XVIII - XIX stoletiyah [Three projects for the organization of learning Oriental languages and the East in the 18th - 19th centuries in Russia] in Formirovanie gumanisticheskih tradicij otechestvennogo vostokovedeniya (do 1917 goda) [Formation of humanistic traditions of Russian Oriental studies (before 1917)].

4. Frähn, Christian Danilovich (1959) (Fond. 778) in Proceedings of the Archive. Vol. 16. Archive of the USSR Academy of Sciences. Review of archival materials. Vol. IV. Moscow - Leningrad.

5. Gerasi, R. P. (2001). Window on the East: National and Imperial Identities in Late Tsarist Russia. Ithaca, NY.

6. Istoriya otechestvennogo vostokovedeniya do serediny XIX veka [History of Russian Oriental studies until the middle of the 19th century] (1990). Moscow.

7. Kiselev, V. S. (2012). "...Chtoby v Rossii zavedena byla Aziatskaya Akademiya: 'Projet d une academie asiatique'" S. S. Uvarova v istorii rossijskogo orientalizma [... In order for an Asian Academy to be established in Russia: S.S. Uvarov's 'Projet d une academie asiatique' in the history of Russian orientalism] in Vestnik Tomskogo gosudarstvennogo universiteta. Philology Series. No. 3 (19).

8. Kulikova, A. M. (1970). Proekty vostokovednogo obrazovaniya v Rossii (XVIII - pervaya polovina XIX v.) [Projects of Oriental education in Russia (18th - first half of the 20th century] in Narody Azii i Afriki [Peoples of Asia and Africa]. No. 4.

9. Kulikova, A. M. (1979). Plan kollezhskogo sovetnika Yankovicha de Mirievo o zavedenii uchilishcha vostochnyh yazykov [Plan of Collegiate Advisor Janković Mirijevski on the establishment of a vocational school of Oriental studies] in XIV annual academic session of the LO Institute of Oriental studies: Proceedings. December 1978. Moscow.

10. Kulikova, A. M. (1982). Stanovlenie universitetskogo vostokovedeniya v Peterburge [The formation of academic Oriental studies in St. Petersburg] Moscow. PP. 141-142.

11. Mikhailova, S. M. Kazanskij universitet i prosveshchenie narodov Povolzh'ya i Priural'ya (XIX vek) [Kazan University and the education of the peoples of the Volga region and the Urals (19th century)]. Kazan.

12. Russian State Historical Archive. F. 733. Op.39. D. 45. "O dostavlenii mneniya Ministerstvu inostrannyh del o zavedenii dlya vostochnyh yazykov uchilishch v Kazanskom uchebnom okruge". 21 avgusta - 22 noyabrya 1806 g. 16 ll. ["On delivering an opinion to the Ministry of Foreign Affairs about the establishment of vocational schools for Oriental languages in Kazan School District". August 21-November 22, 1806. 16 pages.]. 
13. Shamov, G. F. (1956). Rol' vostokovedov Kazanskogo universiteta v izuchenii Mongolii i Kitaya (pervaya polovina XIX veka) [The role of the orientalists of Kazan University in the research of Mongolia and China (the first half of the 19th century)]: dissertation ... Candidate of Historical Sciences. Kazan.

14. Voronov, A. (1858). Fedor Ivanovich Yankovich de Mirievo, ili Narodnye uchilishcha v Rossii pri imperatrice Ekaterine II [Teodor Janković Mirijevski, or Public vocational schools in Russia under Empress Catherine II]. Saint Petersburg. 